\title{
EVALUASI PELAKSANAAN PROGRAM KAWASAN RUMAH PANGAN LESTARI DI KECAMATAN GANGGA KABUPATEN LOMBOK UTARA
}

\author{
EVALUATION OF THE IMPLEMENTATION OF SUSTAINABLE \\ FOOD HOUSE AREA PROGRAM IN GANGGA, NORTH LOMBOK
}

\author{
Erni Hidayati, Taslim Sjah, dan I Gusti Lanang Parta Tanaya \\ Program Studi Agribisnis Fakultas Pertanian UNRAM
}

\begin{abstract}
ABSTRAK
Tujuan penelitian ini adalah untuk mengevaluasi pelaksanaan program kawasan rumah pangan lestari di Kecamatan Gangga Kabupaten Lombok Utara dan menganalisis kendala-kendala yang dihadapi oleh pelaku usaha pekarangan. Metode yang digunakan dalam penelitian ini adalah metode deskriptif. Penentuan daerah penelitian ini ditentukan secara purposive sampling karena desa tersebut merupakan desa yang pertama kali menerapkan KRPL dengan memilih Kecamatan Gangga. Penentuan jumlah responden dilakukan secara quota sampling dengan menetapkan 30 responden dari pelaku usaha. Pelaku usaha pekarangan dipilih secara accidental sampling. Hasil penelitian menunjukkan bahwa pelaksanaan program KRPL di Kecamatan Gangga Kabupaten Lombok Utara dinilai berhasil, dan perlu diprogramkan di lokasi-lokasi lain.
\end{abstract}

Kata kunci : Evaluasi program, usahatani pekarangan, Pertanian lahan kering

\begin{abstract}
The purpose of the this research is to evaluate the implementation of the program of sustainable food hause area program in Gangga District, North Lombok Regency and also to analyze the problem faced in implementing the program in Gangga District North Lombok Regency. The method that used in this research was descriptive method. The area of the research was determined by purposive sampling as the area is the first that implemented the program. Respondents were set as 30 persons and were selected accidentally according to their availability on the of survey is considered succesful. The study showed that the implementation of KRPL program in Gangga District North Lombok Regency was successful, and needs to be programmed in other locations.
\end{abstract}

Keywords: Program evaluation, Houseyard farming, Dryland Agriculture 


\section{PENDAHULUAN}

Indonesia merupakan negara agraris, yang kaya akan ketersediaan pangan yang beraneka ragam. Hal ini disebabkan karena kondisi iklim dan letak geografis yang sangat menunjang (Aprillianida, 2016). Pangan sangat erat kaitannya dengan kelangsungan hidup suatu bangsa, ketersediaan pangan dalam jumlah dan kualitas gizi yang baik, akan berpengaruh terhadap kualitas sumberdaya manusia (Lidayya, 2016). Undang-Undang (UU) No.7 tahun 1996 tentang pangan pasal 1 ayat 17 menyebutkan bahwa ketahanan pangan adalah kondisi terpenuhinya pangan rumah tangga (RT) yang tercermin dari tersedianya pangan yang cukup, baik jumlah maupun mutunya, aman, merata dan terjangkau (Tambunan, 2010).

Pangan merupakan kebutuhan hak asasi manusia, karena pemenuhan kebutuhan pangan bagi setiap individu dijamin oleh Undang-Undang Nomor 18 Tahun 2012 yang mengandung tentang pangan. Tidak hanya sekedar memenuhi pangan tetapi juga bagaimana kualitas pangan yang dikonsumsi oleh masyarakat untuk meningkatkan kualitas gizi (Menteri Pertanian RI, 2017). Salah-satu ukuran pokok dari tingkat kesejahteraan masyarakat yaitu kemampuannya untuk mendapatkan pangan yang bergizi, aman dan cukup (Lidayya, 2016).

Badan Ketahanan Pangan melalui Pusat Penganekaragaman Konsumsi dan Keamanan Pangan, kini kembali meluncurkan program Optimalisasi Pemanfaatan Pekarangan Melalui Konsep Kawasan Rumah Pangan Lestari guna mempercepat diversifikasi pangan dan memperkuat ketahanan pangan masyarakat. Dengan adanya anjuran pemanfaatan pekarangan sangatlah tepat untuk memenuhi pangan dan gizi keluarga (Menteri Pertanian RI, 2017).

Kawasan Rumah Pangan Lestari (KRPL) merupakan salah satu program Kementerian Pertanian yang dibangun dengan tujuan yaitu: (1) memenuhi kebutuhan pangan dan gizi keluarga dan masyarakat secara lestari, (2) meningkatkan kemampuan keluarga dan masyarakat perkotaan maupun pedesaan untuk budidaya tanaman dan diversifikasi pangan, serta (3) mengembangkan sumber bibit untuk menjaga keberlanjutan pemanfaatan lahan pekarangan dan melakukan pelestarian tanaman pangan lokal (Gunawan \& Werdhany 2012). Berdasarkan kajian BPTP Jawa Timur di Pacitan menunjukkan bahwa penerapan program KRPL dapat mengurangi belanja Ibu rumahtangga sekitar Rp 195.000 - Rp 650.000 per bulan (Fratiwi, 2016).

Sasaran yang ingin dicapai dari program KRPL adalah berkembangnya kemampuan keluarga dan masyarakat secara ekonomi dan sosial, dalam memenuhi kebutuhan pangan dan gizi secara lestari, menuju keluarga dan masyarakat yang mandiri dan sejahtera. Prinsip yang diterapkan dalam Program Rumah Pangan Lestari (RPL) adalah: kemandirian pangan, diversifikasi pangan berbasis sumber pangan lokal, pelestarian sumber daya genetik pangan dan kebun bibit (Gunawan \& Werdhany, 2012).

Pelaksanaan program KRPL di Nusa Tenggara Barat telah dikembangkan pada tahun 2015. Program KRPL ini dikembangkan berdasarkan potensi-potensi yang ada sebagai basis ekonomi yang produktif bagi rumah tangga, dalam rangka mendukung terwujudnya ketahanan pangan nasional khususnya di Pulau Lombok yang mendapatkan program KRPL pada tahun 2015 di tingkat kabupaten atau kota salah satunya wilayah Kabupaten Lombok Utara (BKP, 2015 dalam Fratiwi, 2016). Kabupaten Lombok Utara pada tahun 2012 memiliki luas pekarangan sebesar 2.285 ha artinya wilayah tersebut memiliki pekarangan yang cukup luas sehingga memiliki 
potensi untuk melakukan pemanfaatan lahan pekarangan guna mencukupi kebutuhan pangan keluarga.

Pada tahun 2012 terdapat luas area pekarangan di Kecamatan Gangga sebesar 226 ha. Sehingga dapat dikatakan bahwa wilayah di Kecamatan Gangga memiliki luas pekarangan yang paling sedikit jika dibandingkan dengan Kecamatan Tanjung, Pemenang, Kayangan dan Bayan. Maka hal tersebut menunjukkan optimalisasi pemanfaatan pekarangan harus dioptimalkan guna mendapatkan pangan yang cukup, seimbang dan aman. Pada saat pelaksanaan program KRPL yang dilakukan oleh pelaku usaha pekarangan ada saja kendala pada saat pelaksanaannya. Oleh karena itu, perlu dilakukan evaluasi untuk mengetahui dan menilai pelaksanaan program tersebut dalam mencapai sasaran dan tujuan program serta hasilnya. Tujuan Penelitian : (1) Mengevaluasi pelaksanaan program Kawasan Rumah Pangan Lestari (KRPL) di Kecamatan Gangga Kabupaten Lombok Utara; (2) Untuk menganalisis kendalakendala yang dihadapi oleh pelaku usaha pekarangan dalam pelaksanaan kegiatan pemanfaatan pekarangan melalui program Kawasan Rumah Pangan Lestari (KRPL) di Kecamatan Gangga Kabupaten Lombok Utara.

\section{METODE PENELITIAN}

Metode yang digunakan dalam penelitian ini adalah metode deskriptif yaitu metode yang bertujuan untuk memecahkan masalah yang ada pada waktu sekarang dengan cara mengumpulkan data, menyusun, menganalisis dan menyimpulkannya, alat pengumpulan data menggunakan kuesioner yaitu sejumlah pertanyaan tertulis yang digunakan untuk memperoleh informasi dari responden (Hasan, 2002). Unit analisis dalam penelitian ini, adalah pelaku usaha pekarangan yang tergabung dalam kelompok wanita tani (KWT) yang mendapatkan program pemanfaatan pekarangan melalui konsep Kawasan Rumah Pangan Lestari (KRPL).

Penentuan daerah sampel ditentukan secara sengaja (purposive sampling) dengan pertimbangan bahwa Kecamatan tersebut merupakan Kecamatan yang mendapatkan program Kawasan Rumah Pangan Lestari (KRPL) yang ada di Kabupaten Lombok Utara. Selanjutnya pemilihan desa yakni desa Genggelang dipilih secara purposive sampling karena desa tersebut menjadi prioritas yang melaksanakan program KRPL. Dari desa tersebut kemudian dipilih dusun Gangga penentuan dusun Gangga dilakukan karena dusun tersebut telah melaksanakan program KRPL. Penentuan jumlah responden dalam penelitian ini dilakukan secara quota sampling dengan menetapkan 30 responden dari pelaku usaha. Pelaku usaha pekarangan yang dijadikan responden dipilih secara accidental sampling karena ketersediaan responden pada waktu survei.

Analisis yang digunakan dalam penelitian ini dilakukan terhadap pelaksanaan KRPL dan kendala pelaku usaha KRPL. Evaluasi pelaksanaan kawasan rumah pangan lestari dianalisis menggunakan metode analisis deskriptif. Analisis ini untuk memberikan gambaran atau lukisan secara sistematis, faktual dan akurat mengenai fakta, sifat serta hubungan antara fenomena yang diteliti. Aspek yang diteliti. Aspek yang diamati adalah : jenis tanaman, jumlah tanaaman, daya tumbuh (keberhasilan) tanaman, biaya produksi tanaman, produksi tanaman, harga produk, penerimaan 
tanaman dan keuntungan. Evaluasi dilakukan dari kriteria data empiris dengan pedoman atau kriteria dalam Kawasan Rumah Pangan Lestari (KRPL). Untuk menganalisis kendala - kendala yang dihadapi anggota kelompok wanita tani dalam pelaksanaan kegiatan program KRPL menggunakan metode deskriptif sesuai dengan masalah yang dirasakan oleh pelaku usaha pekarangan.

\section{HASIL DAN PEMBAHASAN}

\section{Gambaran Umum Wilayah Penelitian}

Kecamatan Gangga merupakan salah satu kecamatan di Kabupaten Lombok Utara yang memiliki potensi yang sangat besar, memiliki pemandangan alam yang indah tanah yang subur sehingga dapat menghasilkan berbagai sumber daya alam yang bisa dimanfaatkan untuk kebutuhan sehari-hari. Secara umum Kecamatan Gangga dapat digambarkan tentang keadaan geografis dan luas wilayah, keadaan topografi, iklim, curah hujan, tataguna lahan, keadaan penduduk dan mata pencaharian serta sarana dan prasarana. Berkaitan dengan daerah umum penelitian maka batasbatas wilayah Kecamatan Gangga sebelah utara : laut jawa, sebelah timur : kecamatan kayangan, sebelah selatan : kabupaten lombok utara, sebelah barat: kecamatan tanjung (BPS KLU, 2016).

\section{Pelaksanaan Program Kawasan Rumah Pangan Lestari}

Pelaksanaan Program Kawasan Rumah Pangan Lestari (KRPL) di lokasi penelitian Kecamatan Gangga digambarkan dan dievaluasi dari beberapa aspek atau hal-hal sebagai berikut: jenis tanaman, jumlah tanaaman, daya tumbuh (keberhasilan) tanaman, biaya produksi tanaman, produksi tanaman, harga produk, penerimaan tanaman dan keuntungan tanaman.

\section{Indikator Keberhasilan Kawasan Rumah Pangan Lestari (KRPL)}

Indikator pada KRPL diukur untuk menggambarkan keberhasilan KRPL di lokasi penelitian Kecamatan Gangga Kabupaten Lombok Utara. Indikator KRPL tersebut dapat dideskripsikan dari 8 aspek yang sesuai dengan pedoman atau kriteria dalam KRPL. Deskripsi indikator berdasarkan hasil penelitian yang ditemukan di Kecamatan Gangga Kabupaten Lombok Utara sebagai berikut:

Jenis tanaman untuk Kawasan Rumah Pangan Lestari (KRPL) adalah tanaman semusim seperti sayuran dan buah-buahan. Jumlah tanaman pada Kawasan Rumah Pangan Lestari (KRPL) tidak ditentukan, hanya disesuaikan dengan luas pekarangan yang dimiliki. Daya Tumbuh (Keberhasilan) Tanaman dalam evaluasi ini pertumbuhan tanaman KRPL dikatakan berhasil apabila pertumbuhan mencapai $65 \%$. Biaya produksi pada tanaman KRPL digolongkan tercapai bila pelaku usaha pekarangan dapat melakukan penanaman tanpa pinjaman. Produksi Tanaman Penilaian produksi tanaman KRPL didasarkan pada adanya produksi untuk memenuhi kebutuhan konsumsi keluarga. Harga Produk Harga produk untuk tanaman KRPL 
mengacu kepada harga pasar. Penerimaan Tanaman Pelaksanaan KRPL dinilai baik bila memberikan penerimaan yang lebih besar daripada biaya produksi. Keuntungan Tanaman Pelaksanaan KRPL dinilai baik bila memberikan keuntungan bagi pelaku usaha.

\section{Evaluasi Keberhasilan Program KRPL}

Evaluasi keberhasilan program KRPL merupakan penilaian yang dilakukan untuk mengetahui keberhasilan dari suatu program. Evaluasi yang dilakukan terhadap KRPL di lokasi penelitian dapat dinilai dari 8 aspek yaitu jenis tanaman, jumlah tanaman, daya tumbuh (keberhasilan) tanaman, biaya produksi tanaman, produksi tanaman, harga produk, penerimaan tanaman dan keuntungan. Evaluasi pelaksanaan Kawasan Rumah pangan Lestari (KRPL) dideskripsikan sebagai berikut:

\section{Jenis Tanaman yang Diusahakan Dalam Program KRPL}

Rumahtangga masyarakat dianjurkan untuk memanfaatkan pekarangannya dengan berbagai tanaman. Tanpa anjuran pun sebagian rumahtangga sudah menanam berbagai tanaman, diantara tanaman tahunan tersebut biasanya masih ada ruang-ruang kosong yang masih dimanfaatkan. Pemanfaatan tersebut antara lain dengan menanam tanaman-tanaman musiman dan tidak memerlukan ruang yang luas. Program KRPL menganjurkan untuk melakukan pemanfaatan ruang tersebut dengan tanaman-tanaman semusim. Tanaman semusim diantaranya sayuran dan buah-buahan. Seperti yang ditemukan dilokasi penelitian ada 17 tanaman sayuran terdiri dari cabai, tomat, terong, kol, seledri, bayam, pakcoy, pare, kacang panjang, sawi, brokoli, salada, kangkung, timun jepang, ubi kayu, kemangi dan timun. Adapun buah-buahan yang ditanam di lokasi penelitian ada 3 yaitu: pepaya, stroberi dan naga. Jenis tanaman sayuran yang dominan yaitu : Cabai, Tomat, Terong, Saledri dan Salada.

Tanaman-tanaman ini diusahakan oleh lebih dari 10 orang responden, dari tanaman sayuran tersebut cabai merupakan tanaman sayuran yang paling banyak ditanam oleh responden yaitu sebanyak 25 orang atau $83 \%$. Karena cabai memiliki ciri khas rasa pedas sehingga sangat digemari oleh responden, selain itu bibit cabe juga diberikan oleh pemerintah sehingga hampir semua responden menanam tanaman cabai. Secara khusus cabai dan tomat sering digunakan secara bersama dalam bumbu masakan. Juga dapat disampaikan bahwa umumnya orang Lombok sangat menyenangi rasa cabai yang pedas tersebut.

Sejalan dengan banyak petani yang menanam tanaman tertentu, demikian juga dengan jumlah tanaman yang ditanam. Artinya, semakin banyak pelaku yang menanam tanaman tersebut maka semakin banyak pula jumlah tanaman tersebut, walaupun angka-angkanya tidak selalu linier. Namun penilaian terhadap banyak tanaman ini mungkin kurang adil (kurang fair) karena petani memiliki luas pekarangan yang berbeda yaitu ada yang luas dan ada yang sempit. 
Tabel 1. Jenis tanaman dan Pertumbuhan Tanaman KRPL di Kecamatan Gangga, 2017

\begin{tabular}{|c|c|c|c|c|c|}
\hline Jenis tanaman & $\begin{array}{l}\text { Jumlah } \\
\text { Petani } \\
\text { (orang) }\end{array}$ & $\%$ Petani & $\begin{array}{c}\text { Jumlah } \\
\text { Ditanam } \\
\text { (pohon) }\end{array}$ & $\begin{array}{l}\text { Jumlah } \\
\text { Tumbuh } \\
\text { (pohon) }\end{array}$ & $\begin{array}{c}\% \\
\text { Tumbuh }\end{array}$ \\
\hline 1.Cabai & 25 & 83 & 473 & 377 & 80 \\
\hline 2.Tomat & 23 & 77 & 383 & 356 & 93 \\
\hline 3.Terong & 20 & 67 & 260 & 208 & 80 \\
\hline 4.Seledri & 12 & 40 & 103 & 103 & 100 \\
\hline 5.Bayam & 7 & 23 & 130 & 130 & 100 \\
\hline 6.Pepaya & 7 & 23 & 49 & 49 & 100 \\
\hline 7.Pakcoy & 8 & 27 & 149 & 139 & 96 \\
\hline 8.Kul & 5 & 17 & 60 & 40 & 67 \\
\hline 9.Sawi & 5 & 17 & 235 & 215 & 91 \\
\hline 10.Kacang Panjang & 4 & 13 & 272 & 272 & 100 \\
\hline 11.Timun & 3 & 10 & 27 & 21 & 78 \\
\hline 12.Kangkung & 2 & 7 & 10 & 10 & 100 \\
\hline 13.Selada & 12 & 40 & 244 & 229 & 94 \\
\hline 14.Brokoli & 1 & 3 & 54 & 47 & 87 \\
\hline 15.Kemangi & 1 & 3 & 5 & 5 & 100 \\
\hline 16.Naga & 1 & 3 & 3 & 3 & 100 \\
\hline 17.Strowberi & 1 & 3 & 6 & 6 & 100 \\
\hline 18.Timun Jepang & 1 & 3 & 10 & 7 & 70 \\
\hline 19.Ubi Kayu & 1 & 3 & 50 & 50 & 100 \\
\hline 20.Pare & 1 & 3 & 1 & 1 & 100 \\
\hline Rata-rata & 7 & 23 & 126 & 113 & 92 \\
\hline
\end{tabular}

\section{Jumlah tanaman yang diusahakan dalam program KRPL}

Tanaman KRPL yang diusahakan oleh pelaku usaha pekarangan merupakan tanaman yang disubsidi oleh pemerintah ada 20 macam tanaman yang diusahakan oleh rumahtangga-rumahtangga di lahan kering Kecamatan Gangga Kabupaten Lombok Utara. Di luar tanaman tahunan, tanaman-tanaman semusim yang diusahakan termasuk: Cabai, Tomat, Terong, Seledri, Bayam, Pepaya, Pakcoy, Kol, Sawi, Kacang panjang, Timun, Kangkung, Selada, Brokoli, Kemangi, Naga, Strowberi, Timun Jepang, Ubi kayu dan pare. Dari daftar ini tampak bahwa sebagian besar tanaman yang ditanam di pekarangan rumah ini merupakan tanaman sayuran adapula tanaman buah-buahan. Pemilihan tanaman sayuran ini tampaknya terkait dengan kebutuhan konsumsi rumahtangga yang bersangkutan, dalam arti bahwa sebagian dari tanaman 
ini dimanfaatkan untuk memenuhi kebutuhan keluarga sendiri, selain untuk dijual. Hampir semua tanaman tersebut ditemukan di pekarangan rumah.

\section{Daya Tumbuh (keberhasilan) Tanaman KRPL}

Daya tumbuh (keberhasilan) tanaman dipengaruhi oleh cuaca/iklim serta perawatan yang rutin, semakin intensif dilakukan perawatan/proteksi terhadap tanaman, maka keberhasilan tumbuh tanaman akan semakin meningkat sesuai dengan yang ditemukan dilokasi penelitian persentase (\%) keberahasilan tumbuh tanaman hingga $100 \%$ dengan rata-rata 92\%. Berdasarkan kisaran rata-rata keberhasilan tumbuh tanaman maka dapat dievaluasi bahwa daya tumbuh tanaman sangat tinggi Disisi lain, ada pula tanaman yang tumbuh semua seperti tanaman Saladri, Bayam, Pepaya, Kacang Panjang, Kangkung, Kemangi, Naga, Stroberi, Ubi Kayu dan Pare.

Evaluasi terhadap kerberhasilan program KRPL ini antara lain dapat dilihat dari keberhasilan tumbuh tanaman. Keberhasilan tumbuh tanaman cukup tinggi dengan rata-rata keberhasilan tumbuh mencapai 92\%, bahkan banyak diantara tanaman tersebut tumbuh $100 \%$ (Tabel 1). Pelaksanaan program KRPL berjalan dengan baik karena selain didukung dengan keberhasilan tumbuh yang cukup tinggi, didukung pula dengan jumlah petani yang ikut serta dalam pelaksanaan program KRPL.

\section{Biaya Produksi Tanaman KRPL}

Biaya produksi pada tanaman KRPL terdiri dari biaya bibit, pupuk1, pupuk2, obat1, obat2, air dan tenaga kerja. Biaya-biaya produksi yang dikeluarkan oleh rumahtangga tergolong cukup mudah dilakukan karena rumahtangga tidak terus menerus mengeluarkan biaya produksi melainkan pemerintah membantu rumahtangga tersebut dengan cara memberikan subsidi gratis kepada rumahtangga atau pelaku usaha pekarangan subsidi tersebut terdiri dari pemberian polibag, bibit gratis diantaranya bibit cabe, tomat, salada, pakcoy, saladri, terong, kemangi, stroberi, pare dan sawi, serta pemberian alat untuk pembuatan pupuk kompos. Berdasarkan Tabel 2 ada 6 jenis tanaman yang tidak mengeluarkan biaya produksi yaitu: seledri, sawi, kemangi, pare, stroberi dan pakcoy. Biaya yang tidak dikeluarkan karena bibit gratis, menggunakan pupuk kompos yang dibuat sendiri serta pembuatan pestisida alami sebagai obat bagi hama/penyakit. Maka dapat dievaluasi bahwa pelaku usaha pekarangan memperoleh kemudahan pada pengeluaran biaya produksi. 
Tabel 2. Jenis Tanaman, Biaya Produksi, Produksi, Harga, Penerimaan dan Keuntungan

\begin{tabular}{|l|r|r|r|r|r|}
\hline \multicolumn{1}{|c|}{ Jenis tanaman } & $\begin{array}{c}\text { Biaya } \\
\text { Produksi } \\
(\mathrm{Rp})\end{array}$ & $\begin{array}{c}\text { Produksi } \\
(\mathrm{kg})\end{array}$ & \multicolumn{1}{c|}{$\begin{array}{c}\text { Harga } \\
(\mathrm{Rp})\end{array}$} & $\begin{array}{c}\text { Penerimaan } \\
(\mathrm{Rp})\end{array}$ & $\begin{array}{l}\text { Keuntungan } \\
(\mathrm{Rp})\end{array}$ \\
\hline 1. Cabai & 31.143 & 3.53 & 11.841 & 41.799 & 10.656 \\
\hline 2. Tomat & 27.538 & 6.68 & 5.048 & 33.721 & 6.183 \\
\hline 3. Terong & 24.182 & 3.59 & 6.812 & 24.455 & 273 \\
\hline 4. Seledri & 0 & 1.36 & 6.500 & 8.840 & 8.840 \\
\hline 5. Bayam & 13.750 & 1.67 & 9.667 & 16.144 & 2.394 \\
\hline 6. Pepaya & 37.667 & 7.20 & 12.800 & 92.160 & 54.493 \\
\hline 7. Pakcoy & 0 & 1.50 & 9.562 & 14.343 & 14.343 \\
\hline 8. Kol & 28.000 & 4.50 & 6.400 & 28.800 & 800 \\
\hline 9. Sawi & 0 & 3.60 & 4.400 & 15.840 & 15.840 \\
\hline 10. Kacang Panjang & 38.000 & 38 & 9.750 & 370.500 & 332.500 \\
\hline 11. Timun & 5.000 & 3 & 5.500 & 16.500 & 11.500 \\
\hline 12. Kangkung & 20.000 & 2 & 15.000 & 30.000 & 10.000 \\
\hline 13. Selada & 17.923 & 2.02 & 16.571 & 33.473 & 15.550 \\
\hline 14. Brokoli & 35.000 & 20 & 12.000 & 240.000 & 205.000 \\
\hline 15. Kemangi & 0 & 5 & 2.000 & 10.000 & 10.000 \\
\hline 16. Naga & 45.000 & 15 & 15.000 & 225.000 & 180.000 \\
\hline 17. Strowberi & 0 & 3 & 20.000 & 60.000 & 60.000 \\
\hline 18. Timun Jepang & 20.000 & 2 & 20.000 & 40.000 & 20.000 \\
\hline 19. Ubi Kayu & 45.000 & 50 & 4.000 & 200.000 & 155.000 \\
\hline 20. Pare & 0 & 0.50 & 10.000 & 5.000 & 5.000 \\
\hline \multicolumn{1}{|c|}{ Rata-rata } & 27.729 & 16.875 & 9.624 & 76.136 & 55.704 \\
\hline
\end{tabular}

\section{Produksi Tanaman KRPL}

Produksi tanaman KRPL dipengaruhi oleh keberhasilan tumbuh tanaman yang sudah berhasil. Keberhasilan tumbuh tanaman dipengaruhi oleh cuaca/iklim yang bagus serta perawatan/proteksi tanaman yang rutin berdasarkan Tabel 2 diperoleh kisaran produksi mulai dari $0,50 \mathrm{~kg}-50 \mathrm{~kg}$. Evaluasi terhadap produksi tanaman yaitu cukup tinggi hingga $50 \mathrm{~kg}$. Produksi yang cukup tinggi ini pula didukung oleh tanaman yang tumbuh hingga 100\% (Tabel 1).

\section{Harga Produk Tanaman KRPL}

Penentuan Harga produk dari tanaman KRPL disesuaikan dengan harga pasar (Rp/unit) mulai dari harga yang paling rendah Rp. 2000 - Rp.20.000/unit. Harga yang 
disesuaikan dengan pasar dapat bersaing sehingga dapat memudahkan arus jual beli dari produk tanaman KRPL.

\section{Penerimaan Tanaman KRPL}

Rumahtangga yang mengikuti program KRPL ada rumahtangga yang tidak memperoleh penerimaan dan adapula yang memperoleh penerimaan. Rumahtangga yang tidak memperoleh penerimaan dari tanaman KRPL sebanyak 7 orang dan yang memperoleh penerimaan sebanyak 23 orang. Penerimaan yang tidak diperoleh dengan adanya program KRPL disebabkan karena tanaman tidak tumbuh bahkan ada tanaman yang tumbuh tapi tidak ada produksi sehingga tidak memperoleh penerimaan. Jumlah rumahtangga yang memperoleh penerimaan cukup banyak dengan demikian, rumahtangga tersebut menerima penerimaan yang merupakan akumulasi dari berbagai tanaman. penerimaan dari usaha tanaman di pekarangan ini merupakan penerimaan tambahan bagi rumahtangga terhadap penerimaan dari pekerjaan pokok rumahtangga tersebut. Usaha pekarangan ini merupakan usaha sampingan, hobby, dan pengisi waktu luang, serta sarana bersosialisasi dengan tetangga. Dengan adanya program KRPL ini, dapat membantu rumahtangga untuk menghemat pengeluaran belanja khususnya pengeluaran untuk pangan. Selain itu dapat membantu mencukupi pangan rumahtangga yang seimbang, bermutu dan bergizi. Evaluasi terhadap penerImaan tanaman dapat dilihat pada Tabel 2, yaitu penerimaan hingga ratusan ribu. Penerimaan yang sangat tinggi pada tanaman kacang panjang sebesar Rp 370.500.

\section{Keuntungan tanaman KRPL}

Keuntungan merupakan nilai lebih yang diperoleh dari suatu usaha khususnya usaha pekarangan, dengan adanya keuntungan dapat meningkatkan kesejahteraan pelaku usaha pekarangan, keuntungan pula dapat digunakan untuk memenuhi kebutuhan sehari - hari untuk dikonsumsi maupun ditabung. Adanya kelebihan yang diperoleh pada keuntungan dapat dijadikan sebagai modal usaha untuk memutar kembali modal tersebut. Modal yang sebelumnya diperoleh dari hasil pinjaman di bank dapat dikembalikan lagi dari keuntungan yang ada. Oleh sebab itu rata - rata keuntungan diperoleh dari tanaman KRPL hingga ratusan ribu yang paling tinggi yaitu pada tanaman Kacang panjang dengan keuntungan sebesar Rp. 332.500. Berdasarkan Tabel 2 semua tanaman memberikan keuntungan mulai dari Rp. 2.208 - Rp. 332.500 hal ini berarti pelaksanaan program KRPL di lokasi penelitian menguntungkan bagi pelaku usaha pekarangan.

\section{Tindak Lanjut}

Dari pelaksanaan program Kawasan Rumah Pangan Lestari yang telah dilakukan di Kecamatan Gangga,program ini perlu dilanjutkan serta perlu lebih diintensifkan dengan penambahan jumlah tanaman per luas yang ada atau memperbaiki teknik penanaman, misalnya dengan teknik vertikultur, sehingga dapat menampung lebih banyak tanaman. Peningkatan produksi pangan dari hasil tanaman ini dapat meningkatkan ketahanan pangan dari sisi ketersediaan pangan dan konsumsi pangan, sedangkan pendapatan yang diperoleh dari usaha tanaman di pekarangan ini dapat dipergunakan untuk meningkatkan ketahanan pangan dari sisi akses terhadap 
pangan.Bila hasil dari produksi pekarangan sudah tinggi maka perlu dilakukan kegiatan pelatihan pengolahan untuk menciptakan kegunaan bentuk, tempat, dan waktu terhadap hasil pertanian pekarangan tersebut. Juga, diperlukan fasilitasi tentang pencarian informasi yang berguna bagi pemasaran produk, baik produk segar hasil pekarangan maupun produk olahannya.

\section{Kendala-Kendala yang Dihadapi Pelaku Usaha Pekarangan dalam Pelaksanaan Program KRPL Di Kecamatan Gangga Kabupaten Lombok Utara}

Berdasarkan hasil penelitian, kendala-kendala yang dihadapi pelaku usaha pekarangan pada saat penerapan program KRPL di pekarangan yaitu disebabkan karena serangan hama tanaman, cuaca/iklim yang tidak menentu, terbatasnya pemasaran hasil pekarangan, gangguan kesehatan pelaku usaha pekarangan dan kurangnya proteksi ternak, untuk lebih jelasnya dapat diuraikan sebagai berikut.

Hama merupakan salah satu penganggu tanaman yang dapat menyebabkan tanaman tidak bisa tumbuh dengan baik, sehingga dapat mempengaruhi hasil produksi dari suatu tanaman. Ada berbagai dampak fisik yang disebabkan oleh hama yaitu terdapat pada daun tanaman yang menguning, bolong-bolong dan rusak terutama pada tanaman pekarangan salah-satunya sayuran kol. Oleh sebab itu hasil tanaman yang diperoleh sedikit bahkan tidak ada.

Cuaca yang terlalu ekstrim seperti pada saat musim hujan, dapat merusak tanaman tomat yang ditanam oleh pelaku usaha pekarangan, tanaman mereka busuk dan rusak karena tanaman ini, tidak tahan terhadap hujan. Oleh karena itu akibat dari cuaca yang berubah - ubah berdampak pada tanaman yang ditanam sehingga hasilnya pun berkurang untuk pemenuhan kebutuhan sehari-hari.

Dari hasil produksi tanaman pekarangan tidak hanya dikonsumsi, akan tetapi dijual pula. Namun berdasarkan hasil penelitian ada beberapa responden yang kebingungan dalam memasarkan tanamannya seperti pemasaran tanaman tomat. Produksi tanaman tomat pada saat itu banyak, karena mereka tidak tahu kemana pemasaran tomat, akibatnya tanaman tersebut rusak. Karena tomat tidak sekaligus bisa dihabiskan untuk dikonsumsi

Pelaku usaha pekarangan yang mengalami gangguan kesehatan seperti akibat keguguran. Kesehatan menjadi terganggu yang mengakibatkan tenaga untuk bekerja menjadi lemah maka akan menyebabkan tanaman KRPL yang ditanam pada pekarangan menjadi tidak terurus akibatnya perolehan akan hasil produksi tanaman menjadi tidak ada.

Ternak/unggas pada Kawasan Rumah Pangan Lestari (KRPL) di lokasi penelitian dibiarkan berkeliaran di sekitar tanaman, akibatnya tanaman yang tumbuh dimakan oleh ternak/unggas bahkan tanaman dirusak..Menurut sebaran pelaku usaha pekarangan di Kecamatan Gangga hanya 50\% pelaku usaha pekarangan yang mengurus tanaman pekarangannya. Sisanya 50\% tidak mengurus tanaman pekarangannya. 


\section{KESIMPULAN DAN SARAN}

\section{Kesimpulan}

1. Pelaksanaan Kawasan Rumah Pangan Lestari di Kecamatan Gangga dinilai berhasil. Ada 20 macam tanaman yang diusahakan, dan tumbuh $92 \%$ dari tanaman yang ditanam. Biaya produksi tanaman dapat dipenuhi sendiri oleh pelaku usaha, dan usaha ini memberikan keuntungan hingga Rp. 332.500 per tanaman

2. Pelaksanaan program KRPL di Kecamatan Gangga, memiliki beberapa kendala yang dirasakan oleh pelaku usaha pekarangan yaitu : serangan hama tanaman, gangguan kesehatan pelaku usaha pekarangan, cuaca/iklim yang tidak menentu, terbatasnya pemasaran hasil tanaman pekarangan dan kurangnya proteksi ternak

\section{Saran}

Berdasarkan penelitian tentang program kawasan rumah pangan lestari (KRPL) diajukan beberapa saran sebagai berikut :

1. Untuk mencapai keberhasilan yang optimal dalam pelaksanaan program KRPL maka perlu ditingkatkan kerjasama berbagai pihak stakeholder, sehingga macam tanaman pada setiap petani menjadi lebih banyak dan mencukupi kebutuhan pangan mereka.

2. Perlunya kesadaran dari pelaku usaha pekarangan untuk menjaga tanaman pekarangannya baik itu merawat tanaman serta memproteksi tanaman pekarangan.

\section{DAFTAR PUSTAKA}

Aprillianida, N. 2016. Evaluasi Dampak Program Kawasan Rumah Pangan Lestari (KRPL) Dalam Upaya Pemberdayaan Masyarakat Oleh Yayasan Gerakan Peduli Lingkungan (YGPL) Di Pondok Pekayon. Indah-Pekayon Jaya Bekasi. Skripsi S1 Fakultas Ilmu Dakwah dan Ilmu Komunikasi. Universitas Islam Negeri Syarif Hidayatulloh. Jakarta.

Badan Litbang Pertanian RI. 2017. Kawasan Rumah Pangan Lestari. Kementerian Pertanian. Jakarta.

BPS KLU, 2017. Gangga Dalam Angka. Badan Pusat Statistik. Kabupaten Lombok Utara.Tanjung. 
BPS KLU. 2014. Lombok Utara Dalam Angka 2014 (North Lombok in Figures 2014). Badan Pusat Statistik Lombok Utara. Central Body of Statistics of North Lombok. Tanjung.

Fratiwi, T. 2016. Partisipasi Anggota Kelompok Wanita Tani Dalam Program Rumah Pangan Lestari (KRPL) di Kabupaten Lombok Barat. Skripsi S1. Fakultas Pertanian. Universitas Mataram. Mataram.

Gunawan \& Werdhany, W.I. 2012. Petunjuk Teknis Pengembangan Kawasan Rumah Pangan Lestari Daerah Istimewa Yogyakarta. Balai Pengkajian Teknologi Pertanian Yogyakarta. Yogyakarta.

Hasan, I. 2002. Pokok - Pokok Materi Metodologi Penelitian dan Aplikasinya. PT. Ghalia Indonesia. Jakarta.

Ilyas, B.1988. Kajian Faktor-Faktor Sosial Ekonomi yang Mempengaruhi Fertilitas Pasangan Usia Subur dalam Rangka Pengelolaan Kependudukan (Studi kasus di Kotamadya Ujung pandang) [tesis]. Fakultas pascasarjana, Institut Pertanian Bogor. Bogor.

Lidayya, S.R. 2016. Pelaksanaan Program Kawasan Rumah Pangan Lestari Dalam Rangka Ketahanan Pangan Rumah Tangga: Studi pada Kelompok Wanita Pelaksana Program Kawasan Rumah Pangan Lestari di Kota Mataram. Skripsi S1. Fakultas Pertanian. Universitas Mataram. Mataram.

Menteri Pertanian RI. 2017. Pedoman Teknis Optimalisasi Pemanfaatan Lahan PekaranganMelalui Kawasan Rumah Pangan Lestari.Menteri Pertanian RI. Jakarta.

MPSS Kabupaten Lombok Utara. 2012._Kerangka Kerja Logis Sanitasi. Lombok Utara, Tanjung.

Tambunan, T. 2010. Pembangunan Pertanian dan Ketahanan Pangan. UI-Press. Jakarta. 